See discussions, stats, and author profiles for this publication at: https://www.researchgate.net/publication/332536655

\title{
Getting a Second Chance with a University Education: Barriers \&
} Opportunities

Article in Interchange April 2019

DOI: $10.1007 / 510780-019-09354-4$

CITATION

1

1 author:

Jeffrey lan Ross

University of Baltimore

149 PUBLICATIONS 1,296 CITATIONS

SEE PROFILE

Some of the authors of this publication are also working on these related projects:

Project

The Popular Culture of Corrections View project

Project Violence View project
READS

93 


\section{Getting a Second Chance with a University Education: Barriers \& Opportunities}

\section{Jeffrey Ian Ross}

Interchange

A Quarterly Review of Education

ISSN 0826-4805

Interchange

DOI 10.1007/s10780-019-09354-4
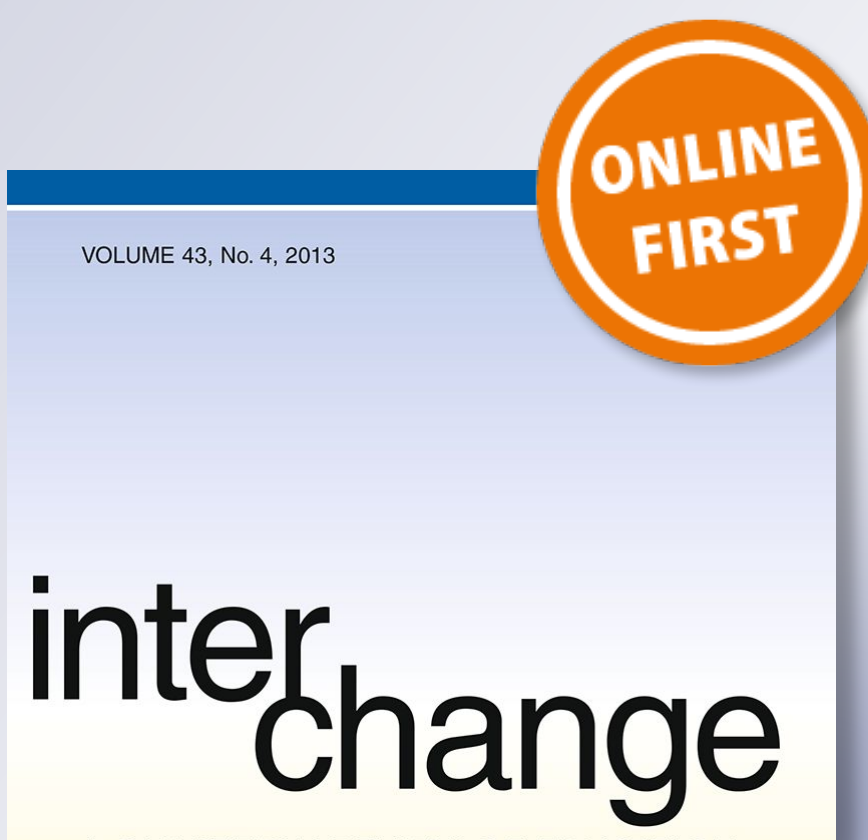

A QUARTERLY REVIEW OF EDUCATION

䌼 Springer

PUBLISHED IN COOPERATION WITH

THE FACULTY OF EDUCATION, THE UNIVERSITY OF CALGARY 
Your article is protected by copyright and all rights are held exclusively by Springer Nature B.V.. This e-offprint is for personal use only and shall not be self-archived in electronic repositories. If you wish to self-archive your article, please use the accepted manuscript version for posting on your own website. You may further deposit the accepted manuscript version in any repository, provided it is only made publicly available $\mathbf{1 2}$ months after official publication or later and provided acknowledgement is given to the original source of publication and a link is inserted to the published article on Springer's website. The link must be accompanied by the following text: "The final publication is available at link.springer.com". 


\title{
Getting a Second Chance with a University Education: Barriers \& Opportunities
}

\author{
Jeffrey lan Ross ${ }^{1,2}$ (D) \\ Received: 24 July 2018 / Accepted: 8 April 2019 \\ (c) Springer Nature B.V. 2019
}

\begin{abstract}
As part of the prisoner reentry process, many formerly incarcerated individuals are choosing to enroll in universities to earn bachelor's, master's, and doctoral degrees. Some cannot immediately begin their studies and must take remedial classes. Others, because of preparations they have done before release, can start classes on the first day of school. The following paper poses and attempts to answer six interrelated questions connected to excons taking classes at universities, the challenges they encounter, and ways to smooth the process for the universities in general and faculty, staff, administrators, and other students in particular.
\end{abstract}

Keywords Prisoner reentry $\cdot$ Prisoner education $\cdot$ Rehabilitation $\cdot$ Convict criminology

\section{Introduction}

Universities ${ }^{1}$ have increasingly become complex, monolithic, resource-intense institutions responsible for training and credentialing the next generation of workers, managers, and leaders (Cabrera 1995). Into this realm people with criminal records, including exconvicts, also known as formerly incarcerated citizens, are entering as students. $^{2}$ As this article argues, overall this is a good thing. But the option of pursuing a university education for exconvicts is not without its challenges.

In order to understand these hurdles, as well as appropriate ways to lessen their impact, I attempt to address six interrelated questions.

\footnotetext{
1 An earlier version of this article was presented at University of Illinois at Chicago, Wednesday, April $18,2018$.

${ }^{2}$ I use the terms exconvicts and formerly incarcerated citizens interchangeably.

Jeffrey Ian Ross

jross@ubalt.edu

1 University of Baltimore, Baltimore, USA

2 Kriminologie, Kriminal Politik, Polizeiwissenschaft, ruhr-universität, Bochum, Germany
} 
- What barriers do formerly incarcerated students face in their attempts to enroll and take classes at universities?

- What can exconvict students contribute to university life?

- What can universities do to assist formerly incarcerated students?

- What can exconvict students contribute to Criminology/Criminal Justice?

- What can faculty, staff, and students do to best assist formerly incarcerated students?

- What conclusions can be drawn from the answers to these questions?

Before continuing, however, we need to be cautious about a number of issues connected to the questions I am about to answer. First, my discussion is limited to university settings in the United States. Although there is some very interesting and relevant research that has been recently done looking at formerly incarcerated students' experiences in community colleges (Rose 2015; Rose et al. 2017; Dreger 2017), for interests of space and because of significant differences between community colleges and universities, I am not going to review this work, nor attempt to explain it.

Second, although some of what I allude to will be relevant to excons who want to complete a master's or doctoral degree (e.g., Conner and Tewksbury 2012), what I have to say primarily refers to formerly incarcerated students who are attempting to enroll in and earn a bachelor's degree.

Third, no two convicts ${ }^{3}$ are the same. Each of them brings different skills, knowledge, and expectations to the university and educational experience. Four, most convicts and exconvicts do not have more that a GED, and upon release, they are typically either unemployed or underemployed. There are many reasons for this state of affairs, and thus, like the previous point, I am not going to explain them in this forum.

Five, the kinds of educational and vocational programs that inmates are afforded while they are incarcerated are often rare and inadequate. Most convicts are lucky to exit a prison with a GED. ${ }^{4}$ Six, it is very difficult for inmates to get a post-secondary education while they are behind bars (Tewksbury and Ross 2019). Seven, most of the scholarship suggests that earning at the very least a bachelor's degree increases the likelihood that formerly incarcerated citizens will not reoffend or recidivate.

Eight, some of the burden of teaching convicts university-level courses has been borne by programs like Inside-Out, which hire university-level instructors to teach for-credit and not-for-credit classes at local correctional facilities. It is neither my

\footnotetext{
3 Although there are technical differences among the terms convict, inmate, and prisoner, in this article I use them interchangeably.

4 "A 2013 meta-analysis conducted by the RAND Corporation and funded by the Department of Justice found that inmates who received an education while incarcerated were $43 \%$ less likely to be arrested for another crime than those who did not participate in any education programs. But research hasn't been able to answer what kind of education has the best outcome. Some argue vocational programs that teach a trade such as welding or plumbing would help newly released people the most. Others argue that college programs prepare people for work in a rapidly changing economy" (Link 2016).
} 
intent nor desire to discuss these important programs here. ${ }^{5}$ Nine, in the field of corrections, ${ }^{6}$ there is a tendency to consider and sometimes implement well-intentioned rehabilitative programs, policies and practices that have some intuitive appeal, but have not been subjected to rigorous scholarly and/or empirical research. The concept of correctional quackery has been introduced to label these initiatives (Latessa et al. 2002).

Finally, because all programs and policies involve the use of resources, investment issues and the profit motive must be considered. It would be foolhardy to categorically accept an educational program without considering its cost implications and/or to outright reject an initiative because it originated in the private sector, involves the participation of the private sector, and/or has been taken over by the private sector. ${ }^{7}$

Next: Upon what basis am I able to make my claims? I am bringing to this discussion my close to 4 years as a practitioner in the field of corrections, the numerous conversations I have had with convicts, exconvicts, and correctional practitioners, my experiences mentoring many convicts and excons who are or were pursuing different academic degrees, my visits to jails and prisons both in the United States and elsewhere, and the scholarship I have engaged in, and the work I have done as a cofounder of the field of Convict Criminology (Ross and Richards 2003; Jones et al. 2009; Newbold and Ross 2013; Ross et al. 2016). ${ }^{8}$

Additionally, in order to answer some of the questions asked and answered by this article, I informally surveyed my students to get a sense of what they believe are acceptable levels of support for excons who wish to earn an undergraduate education. My efforts here should not be construed as formal scientific research, but a process to assist me and others in trying to better understand some of the challenges that formerly incarcerated students face. As an aside, I noticed that there were differences among students in terms of their responses. In other words, one should not assume that all people and institutions that interact with exconvicts are monolithic or uniform in the resources that they bring to the challenge, since there is considerable diversity in responses based on educational attainment, class, gender, race, ethnicity, and familiarity with the criminal justice system. In other words, just like no two formerly incarcerated individuals are identical, no two educational institutions are the same. Some are better than others for excons, and no two instructors/professors, and/or departments provide identical experiences for formerly incarcerated students.

\footnotetext{
5 For a handful of scholarly articles that review the Inside-Out program, see, for example, Allred (2009), Allred et al. (2013), Hilinski-Rosick and Blackmer (2014), Link (2016), Van Gundy et al. (2013)

6 This phenomenon is not restricted to the field of corrections. In fact, I would argue that many initiatives, not just those promoted and/or administered by the state, are based on gut feelings and emotions, and not on policy science.

${ }^{7}$ For a recent review of programs that offer convicts and excons college instruction see, for example, Sokoloff and Schenck-Fontaine (2016).

8 Thus, despite my attempts to be objective, this research can be criticized for possible problems of reliability and validity because it is by necessity subjective, interpretive, and depends on the multiple contexts to which I have been exposed.
} 


\section{What Barriers do Formerly Incarcerated Students Face in Their Attempts to Enroll and Take Classes at Universities?}

To begin with, in many respects we basically know what convicts who are re-entering society need (Petersilia 2003; Travis 2005; Ross and Richards 2009). However, if we are forced to be more specific when looking at the field of higher education and at what formerly incarcerated students need to enter, survive, and thrive in universities, things become a little more complicated (McTier et al. 2017).

More specifically, what do excons who wish to enroll in a university need? Again this varies based on the level at which formerly incarcerated students want to enter, the programs they wish to study, and whether they are accepted to enter. Many convicts and excons are poorly informed about the different types of institutions of higher education, and many of them, like many of our students, have enrolled in for-profit or not-for-profit universities that have been more than willing to take their hard-earned money and/or subject them to increased financial debt, while providing them with what are, in effect, worthless diplomas and degrees (Ross et al. 2015).

Formerly incarcerated inmates need money to pay for tuition, books and supplies, and suitable living accommodations. This can be garnered through a job, family and/ or friends. Where this financial support is lacking, excons can turn to some grants and loans. Some post secondary programs of study are better than others for excons. The federal government has now reintroduced Pell Grants ${ }^{9}$ (i.e., Second Chance Pell Grants), and there are a number of university/correctional partnerships that are enabling convicts to take classes and enroll at universities upon release. ${ }^{10}$

Sometimes formerly incarcerated students need accommodations. Many excons have difficulties finding suitable housing. That being said, not all universities have student housing, so this can be a moot point. For those post-secondary educational institutions that do provide student housing, obtaining this benefit is often very difficult for excons. This is especially true for students who have been convicted of sexrelated crimes (Oliver 2010). Many students, not to mention parents, are leery about having convicted sex offenders living in student housing with them.

Exconvicts must deal with or overcome not only the fear students have towards them, but also the timidness that faculty, staff, and parents may feel and/or display. Parents may not want their children to attend classes with formerly incarcerated students. Even the most liberally minded instructors and professors may harbor fears about having excons as students. We learn about these attitudes and behaviors from

\footnotetext{
9 A "subsidy the federal government provides for students who need it to pay for college. Federal Pell Grants are limited to students with financial need, who have not earned their first bachelor's degree or whose enrolled in certain post-bachelorette programs through participating institutions.'

10 Pell grants were available for prisoners until 1994, when the program was abandoned. When "the Pell program was disbanded "roughly 23,000 inmates were receiving a total of about \$35 million in Pell funding. That comprised less than $1 \%$ of $\$ 6$ billion awarded to students that year" (Lewis 2018). In 2015, the Obama administration reinstated Pell grants. As a response, some universities started offering classes at local correctional institutions.... According to a recent report in March 2018 by the Marshall Project, there are about "4000 inmates currently enrolled in a Pell-funded program... [who] access to college classes and vocational training."
} 
our colleagues during our conversations and departmental meetings. ${ }^{11}$ Also, "[a]t some schools, a formerly incarcerated student's movements on campus and his or her access to facilities may be restricted. At a number of colleges and universities, campus authorities and state officials may jointly monitor students who have committed certain crimes. The measures are set up based on state requirements, school policy, and the institution's comfort level" (Lantigua-Williams 2016b).

Finally, excon students may need special attention from professors and instructors, because their skills and knowledge are not sufficient to meet the demands of university instruction and campus life. The next section examines in greater detail what each person who works with or takes classes with formerly incarcerated individuals can do to ameliorate this situation. The way that each person interacts is bounded, not only by their experiences, but their past and current formal and informal roles (i.e., instructor, student, excon). And there may be a discrepancy between what people advocate and what they actually do with respect to their interactions.

In terms of application to the university, some convicts can apply directly from prison or jail. This can be a little tricky. Most higher education applications these days are done online, and rarely are inmates allowed to use the Internet to complete this task. Some states still require applicants to complete a criminal history questionnaire, or the Common Application Form, while others, because of "Ban the Box" legislation, no longer require this step (Pierce et al. 2014). ${ }^{12}$

Latingua-Williams outlines how "[s]ome colleges routinely ask an optional criminal background question; some schools are compelled to ask it by the state in which they're located; and, whether intentional or not, more than 600 colleges and universities ask simply because they use Common App to streamline the admissions process. This year, 920,000 unique applicants used Common App to submit 4 million applications, or 4.4 applications per student, according to the organization" (2016a). Lantigua-Williams (2016a) further explains that "[c]ampus officials say the background question helps them learn as much as possible about prospective students and allows them to take steps to keep everyone on campus safe. But opponents say the question-which requires prospective students to check a box if they have criminal histories-is an undue barrier that harms certain groups of students." In January 2018, for example, Maryland passed legislation banning the box on university level applications, which affected not only employers, but universities in the state. At my university, for example, formerly incarcerated persons now have to submit a brief statement outlining their offence, and they are required to meet with the Vice Provost to discuss their offence and where they are in their life.

In terms of student challenges, one of the biggest barriers relates to students' ability to use the Internet and World Wide Web, in particular the use of online components of registration and instruction. This includes accessing and submitting assignments on learning platforms. While incarcerated, prisoners do not typically

\footnotetext{
11 For a review of the experiences of the hiring process of excons with Ph.D.s, see, for example, Ross et al. (2011).

12 For a thoughtful analysis of Ban the Box as it relates to university admission, see, for example, ScottClayton (2017).
} 
have access to this kind of technology; they never touched the Internet. This means that university staff and instructors may have to mentor them quite closely. Excons are also required to get documentation for almost everything, and this often proves difficult for them to do. Getting them a university identification card that will help them get the other pieces of documentation is often a challenge in itself. It is often a catch-22 situation. Students may also need to register for Selective Service, ${ }^{13}$ which many of them did not complete because when they were 18-25, they could not register since they were locked up and/or did not have a fixed mailing address.

There will always be some pushback from universities. This may be due to the additional burden in terms of work that staff might be forced to deal with when admitting students who lack technical sophistication or skills. There may also be some timidity when working on behalf of or assisting ex-felons because of the numerous myths and misperceptions about convicts and exconvicts). (Ross 2003).

\section{What Can Formerly Incarcerated Students Contribute to University Life?}

Many universities are suffering from declining enrollment (Fain 2017). Thus, formerly incarcerated students can be an important (much needed) and/or additional source of revenue for a university (Smith 2017). However, I say this with a word of caution, since as alluded to earlier, many of the private for-profit educational institutions are simply predatory in their practices (Ross et al. 2015).

Because of their years behind bars, formerly incarcerated students are often:

1. More disciplined than their fellow students, because they have lived or have been forced to survive in a highly rule-bound system for months and years;

2. Older than their fellow students, and thus often have additional work and life experiences, which may include different jobs, work experience, and perhaps a family;

3. Often formerly incarcerated students are more patient than their fellow students, because they have had to deal with the large bureaucracy of a correctional facility where they lived and worked for long periods of time. All combined these three factors, mean that excons may be, in many respects, more mature than many entering freshmen.

Formerly incarcerated students can make a significant contribution to student lives. What they provide depends on a number for factors, including what they bring to the table. One has to admit that one of the benefits of a university experience is the kind of people to which students are exposed. That is why many universities try to recruit diverse student bodies- not just in terms of race and ethnicity, but in terms of regional diversity to ensure a healthy mix of in state, out-of-state, and American and foreign students. Formerly incarcerated students might become

${ }^{13}$ In the United States, according to law, all male citizens and non-immigrant citizens between the ages of 18-25 must register for military conscription. 
actively involved in campus politics and assume leadership roles. Or they may prefer to keep their heads down and solely concentrate on their studies.

More specifically, Halkovic and Greene (2015) argue that excon students bring "gifts" to university settings in the following ways: "deconstructing stigma/teaching the university; the desire to do more and give back; intimate knowledge of how systems work on the ground, and bridging relationships between the academy and underserved communities." They add "that students with incarceration experience enhance the academic and civic environment of universities, dispelling the spurious suggestion that they are a risk to campus safety" (p. 759). In short, formerly incarcerated students can share their experiences with other much younger and less experienced students to provide a richer educational experience.

The following caveat, however, must be kept in mind. Although many students who attend university have lived relatively sheltered lives, many excons are often not overly worldly or cosmopolitan in their experiences and beliefs. I am reminded of a story an excon colleague of mine once shared. Shortly after release from prison, he was lining up to register for some university courses, and he thought nothing of offering another student a sip from his can of Coke. In the joints that he had served time in, this gesture was considered a normal thing to do, even an act of generosity. But in a university setting, it resulted in weird looks.

In other words, formerly incarcerated students may lack some of the social graces that we, as academics and professors, normally take for granted. Thus, this can and will lead to some awkward situations.

\section{What Can Universities do to Help Formerly Incarcerated Students?}

Universities can do a number of things to assist excons applying to and enrolling in the university classes, programs, and degrees they offer. With respect to the application process, if a university is a private entity, advocates of former prisoner students can go to their Board of Regents and make a case to "ban the box" in the application process. State universities can likewise lobby their legislatures to pass initiatives to change the application process. Under the principle that there is more strength in numbers, this activity may involve forming alliances with progressive organizations locally, regionally, and nationally, in order to act with a concerted voice.

Universities that are part of the second chance Pell grant program can start teaching classes at correctional facilities with the hope that some of the inmates, upon release, will choose to enroll in their educational institutions. They can also do a handful of things to assist their success once they are on campus.

This assistance may include establishing and funding student organizations that support excons. Murillo (2017) has identified several successful university based student programs directed towards assisting excons. At University of California, Berkeley, for example, formerly incarcerated students founded the Berkeley Underground Scholars, "an award-winning student organization and student support program dedicated to serving and empowering formerly incarcerated students at UC Berkeley" (Murillo 2017). They have done a number of things, including "challenged the stigma of incarceration by facilitating workshops and classroom presentations. USI 
has advocated and supported policy change by working on various campaigns, such as Ban the Box, and California's Proposition 57' (Murillo 2017). ${ }^{14}$

Universities, as part of their broad liberal arts and community service orientation, can also pair willing students as peer mentors with excon students. Another option is to actively engage the development office to secure donations to fund the transition of inmates into university life and to sustain them once enrolled.

Moreover, universities can assist excons by connecting them to appropriate "campus-based services that are normally covered by tuition and fees: tutoring support, food pantries, on-campus jobs, student housing, health and mental health services" (Blount et al. 2017, p. 31). If these entities do not exist, then institutions of higher education should help formerly incarcerated students access local service providers and not simply let them fend for themselves.

\section{What Can Formerly Incarcerated Students Contribute to the Academic Disciplines of Criminology/Criminal Justice?}

Unlike other disciplines, Criminology and Criminal Justice often value practitioner experience. That is why so many criminologists are former law enforcement, parole and probation officers, and lawyers. Underrepresented among these professionals are former criminals. Although there are numerous classes and programs to chose from, for many excons, studying Criminology and Criminal Justice often provides an easy entrée into the world of the university and academia. They have practical experience that they might apply to the scholarly knowledge that they are exposed to. Excon students may also feel some initial mastery of the subject and this may keep them more engaged than with other subjects.

Two things bear mentioning here in this regard. Former law enforcement or corrections professionals may be biased against formerly incarcerated students, or some time may have passed since they interacted with criminals, convicts, and excons. There are also lots of people who become criminologists or who conduct research on Criminology/Criminal Justice who do not have practitioner experience. This shines through in the kinds of questions they ask, what they lecture on, etc. This can be a source of stress. Excons can bring a dose of realism to classroom discussions and other interactions. Sometimes both students and instructors base their perceptions on media-mediated interpretations of crime, criminals, and the criminal justice system. These must be confronted on a regular basis by scholarly research and firsthand experience. Some of the latter can be imparted through practitioners relating what they have experienced.

As long as excons don't continuously tell war stories, they can sometimes liven up classroom discussion. The Convict Criminology network (Ross and Richards 2003), is one such attempt to assist the fields of criminology and criminal justice,

\footnotetext{
${ }^{14}$ USI is the acronym for the Underground Scholars Initiative at the University of California-Berkeley, that advocates for students who have been incarcerated, affected by mass imprisonment and/or detained by law enforcement.
} 
and it has produced a considerable amount of research, mentoring, and activism in this area.

\section{How Can Criminology/Criminal Justice Faculty Best Assist Formerly Incarcerated Students?}

Here are four strategies that can be utilized by Criminology/Criminal Justice faculty to help formerly incarcerated students:

To begin with, some academic disciplines and departments that teach those disciplines may be better fits than others for excons. We are assuming that most formerly incarcerated students will want to take classes in Criminology/Criminal Justice, but many of them either are not interested in taking classes in this subject and/or they want to go in another direction.

Additionally, instructors need to guard against their departments becoming or acting like a "cop shop" (Garner and Lyons 2016). In these contexts, excon students may receive a great deal of hostility, thereby frustrating their attempts to achieve their goal. Tewksbury and Ross (2019) outline a number of strategies that instructors and professors of Criminology and Criminal Justice should pursue when dealing with formerly incarcerated students. These include:

- Adapting to excons' teaching and learning styles;

- Recognizing the trauma instilled by incarceration;

- Respecting the limitations imposed by supervision;

- Ensuring that there is sufficient structure in the courses that professors/instructors teach;

- Understanding that their basic skills may need attention;

- Harnessing the enthusiasm of excon students; and

- Finally, managing formerly incarcerated student's expectations.

\section{What Can Traditional Students do to Enable Formerly Incarcerated Students?}

Many of the university students I have surveyed support formerly incarcerated persons not only being allowed to enroll, but to attend universities. However, they do have some concerns. Although a disproportionate number of university students I surveyed are in favor of specialized grants and loans, they are divided with respect to different kinds and levels of support that excon students should be given.

Although most were okay with the provision of grants and loans for education and housing, and making remedial assistance tailored to the educational needs of excons, they were not very supportive of the university providing things like free meals, books, and tuition. Essentially they did not want any unfair advantage given to excons that they did not have themselves. 
In terms of actions, current students who are so motivated may help lead study groups for formerly incarcerated students, assist with study and writing skills, and may see these opportunities as engaging in community service. It may give traditional university students some sense as to whether they want to work in the field of corrections, human services, and/or social work.

\section{Conclusion}

Understanding the challenges that formerly incarcerated people experience is no easy task. Many of them do not want to be interviewed, and this response is to be expected.

Nevertheless as this article argues, exconvicts contribute to university life and classroom discussions in unique ways, there is general acceptance of them on university campuses, but they must be managed in an effective manner, in order not to make things overly bureaucratic for them.

This article should not be considered an end in itself. Rather it should be a call for action for more research on this area of prisoner reentry. As a collectivity, we should be committed to the academic success of formerly incarcerated students. They have served their time, but it is now our responsibility to lend them a helping hand. I am not saying that we should carry their school books, conduct their research or write their essays, but we should do what we can in our limited free time to make sure that they pass their courses and succeed.

On the horizon is the possibility of the Second Chance Pell grants being stopped or modified under the Trump Administration. Based on the reporting by the Marshall project, "The end of Pell could force schools to scale back their offerings or end the programs all together. Of the 69 colleges and universities chosen, $60 \%$ already had some form of prison education program in place, funded mostly by private dollars. The remaining $40 \%$ were new programs" (Lewis 2016). On the other hand, given the Trump administration's attempt and success in passing criminal justice reform legislation, these premonitions may be a little premature. We are still waiting to get final results of numerous evaluations of numerous programs that were instituted through the Second Chance Pell grants (Kreighbaum 2018).

Meanwhile the Formerly Incarcerated Reenter Society Transformed Safely Transitioning Every Person Act (FIRST STEP Act), passed in December 2018. It mainly focuses on prison and sentencing reform and does not really deal with providing additional funding for educational purposes. This does not mean that additional resources to assist formerly incarcerated to enter into universities and success is dead in the water.

Acknowledgements Special thanks to Professor Andrea Cantora for providing feedback on the University of Baltimore's Second Chance College Program, to Professor Jessica Bird for assisting me with the outline of this paper, and to Ian Winchester, Rachel Hildebrant, and the anonymous reviewers of this article for comments.

\section{Compliance with Ethical Standards}

Ethical approval This article does not contain any studies with human participants performed by any of the authors. 


\section{References}

Allred, S. L. (2009). The inside-out prison exchange program: The impact of structure, content, and readings. Journal of Correctional Education, 60(3), 240-258. https://www.jstor.org/stable/23282 746

Allred, S. L., Belche, N. L., \& Robinson, T. (2013). Relational learning and the inside-out experience: A pathway to building capacities, transformative perspectives, and a deeper understanding of self, community turning. In S. Simone Weil Davis \& B. Sherr Roswell (Eds.), Teaching inside out: A pedagogy of transformation for community-based education (pp. 209-225). New York: Springer.

Blount, T. A., Butler, T., \& Gay, H. (2017). How student recruitment and selection can impact reentry outcomes: Lessons from the Michigan Department of Corrections and Jackson College. Journal of Prison Education and Reentry, 4(1), 29-33. https://doi.org/10.15845/jper.v4i1.1190.

Cabrera, N. C. (1995). Control and prevention of crimes committed by state-supported educational institutions. In J. I. Ross (Ed.), Controlling state crime: An introduction (pp. 163-206). New York: Garland Publishers.

Conner, D. P., \& Tewksbury, R. (2012). Ex-offenders and educational equal access: Doctoral programs in criminology and criminal justice. Critical Criminology: An International Journal, 20(3), 327-340. https://doi.org/10.1007/s10612-011-9142-z.

Dreger, M. L. (2017). Barriers to Postsecondary Education Participation Experienced by Formerly Incarcerated Community College Students, University of Hartford, Doctoral Dissertation.

Fain, P. (2017). Enrollment Slide Continues at Slower Rate. Inside Higher Education, Retrieved from December 20. https:/www.insidehighered.com/news/2017/12/20/national-enrollments-decline-sixth -straight-year-slower-rate downloaded April 26, 2018.

Garner, R., \& Lyons, P. (2016). In defense of cop shop pedagogy. Applied Psychology in Criminal Justice, $12(2), 126-132$.

Halkovic, A., \& Greene, A. C. (2015). Bearing stigma, carrying gifts: What colleges can learn from students with incarceration experience. The Urban Review, 47(4), 759-782. https://doi.org/10.1007/ s11256-015-0333-x.

Hilinski-Rosick, C. M., \& Blackmer, A. N. (2014). An exploratory examination of the impact of the Inside-Out Prison Exchange Program. Journal of Criminal Justice, 25(3), 386-397. https://doi. org/10.1080/10511253.2014.922593.

Jones, R. S., Ross, J. I., Richards, S. C. \& Murphy, D. S. (2009). The first dime: A decade of convict criminology. The Prison Journal, 89(2), 151-171.

Kreighbaum, A. (2018). Building Momentum Behind Prison Education, Inside Higher Education, Retrieved August 29, https://www.insidehighered.com/news/2018/08/29/trump-administrations -renewed-interest-prison-education downloaded February 7, 2019

Lantigua-Williams, J. (2016a). 'Ban the Box' goes to college: When schools ask applicants about their criminal histories, a veneer of campus safety may come at the expense of educational opportunity, Atlantic, Retrieved from April 29, https://www.theatlantic.com/politics/archive/2016/04/ban-thebox-comes-to-campus/480195/ downloaded April 13, 2018

Lantigua-Williams, J. (2016b). When a Classmate Is a Former Inmate Students with criminal records are compelling colleges to rethink what it means to provide opportunity to qualified students. Atlantic, Retrieved from May 5, https://www.theatlantic.com/politics/archive/2016/05/when-a-classmate-isa-former-inmate/480864/ downloaded April 13, 2018

Latessa, E. J., Cullen, F. T., \& Gendreau, P. (2002). Beyond correctional quackery: Professionalism and the possibility of effective treatment. Federal Probation, 66(2), 43-49.

Lewis, N. (2018). The Uncertain Fate of College in Prison, Retrieved from March 29 https://www.thema rshallproject.org/2018/03/28/the-uncertain-fate-of-college-in-prison

Link, T. C. (2016). Breaking down barriers: Review of the implementation of an Inside-Out Prison Exchange program in a jail setting. Journal of Prison Education and Reentry, 3(1), 50-55. https:// doi.org/10.15845/jper.v3i1.923.

McTier, T. S., Santa-Ramirez, S., \& McGuire, K. M. (2017). A prison to school pipeline: College students with criminal records and their transitions into higher education. Journal of Underrepresented and Minority Progress, 1(1), 8-22.

Murillo, D. (2017). Mobilizing formerly incarcerated students in California's Colleges and Universities, http://theopportunityinstitute.org/blog/2017/4/5/mobilizing-formerly-incarcerated-students-in-calif ornias-colleges-and-universities Opportunity Institute Blog, downloaded April 17, 2017. 
Newbold, G., \& Ross, J. I. (2013). Convict criminology at the crossroads. The Prison Journal, 93(1), $3-10$.

Oliver, B. E. (2010). My sentence is over but will my punishment ever end. Dialectical Anthropology, 34(4), 447-451. https://doi.org/10.1007/s10624-010-9165-y.

Petersilia, J. (2003). When prisoners come home. New York, NY: Oxford University Press.

Pierce, M. W., Runyan, C. W., \& Bangdiwala, S. I. (2014). The use of criminal history information in college admissions decisions. Journal of School Violence, 14(4), 359-376. https://doi. org/10.1080/15388220.2013.870061.

Rose, L. H. (2015). Community college students with criminal justice histories and human services education: Glass ceiling. Brick Wall, or a Pathway to Success, Community College Journal of Research and Practice, 39(6), 584-587. https://doi.org/10.1080/10668926.2014.926261.

Rose, L. H., Aikas, R. M., \& Valoy, G. (2017). Human services/social work students with criminal justice involvement and internships: A closer look at the prison to college to career pathway. Dialogues in Social Justice: An Adult Education, 2(2), 102-117.

Ross, J. I. (2003). (Mis) representing Corrections: The Role of our Cultural Industries, in Ross, J. I. \& Richards, S. C. (Eds.) Convict Criminology, (pp. 37- 58). Belmont, CA: Wadsworth Publishing.

Ross, J. I., \& Richards, S. C. (Eds.). (2003). Convict criminology. Belmont, CA: Wadsworth Publishing.

Ross, J. I., \& Richards, S. C. (2009). Beyond bars: Rejoining society after prison. Indianapolis: Alpha Books.

Ross, J. I., Richards, S. C., Newbold, G., Jones, R. S., Lenza, M., Murphy, D. S., et al. (2011). Knocking on the ivory tower's door: The experience of ex-convicts applying for tenure-track university positions. Journal of Criminal Justice Education, 22(2), 267-285. https://doi.org/10.1080/1051125100 3778982.

Ross, J. I., Jones, R. S., Lenza, M., \& Richards, S. C. (2016). Convict criminology and the struggle for inclusion. Critical Criminology: An International Journal, 24(4), 489-501.

Ross, J. I., Tewksbury, R., \& Zaldivar, M. (2015). Analyzing for-profit colleges and universities that offer bachelors, masters and doctorates to inmates incarcerated in American Correctional Facilities. Journal of Offender Rehabilitation, 54(8), 585-598. https://doi.org/10.1080/10509674.2015.1087442.

Scott-Clayton, J. (2017). Thinking 'beyond the box': The use of criminal records in college admissions, Brookings Report. https://www.brookings.edu/research/thinking-beyond-the-box-the-use-of-crimi nal-records-in-college-admissions/

Smith, A. D. (2017). Bridges to a brighter future: University—corrections partnerships as a sustainability issue. In B. D. Wortham-Galvin, J. H. Allen, \& J. Sherman (Eds.), Sustainable solutions: University-community partnerships (pp. 75-88). New York: Taylor \& Francis.

Sokoloff, N. J., \& Schenck-Fontaine, A. (2016). College programs in prison and upon reentry for men and women: A literature review. Criminal Justice Review, 20(1), 95-114. https://doi.org/10.1080/10282 580.2016.1262772.

Tewksbury, R., \& Ross, J. I. (2019). Instructing and mentoring ex-con university students in departments of criminology and criminal justice. Corrections: Policy Practice and Research, 4(2), 79-88 https:// doi.org/10.1080/23774657.2017.1387081.

Travis, J. (2005). But they all come back. Washington, DC: Urban Institute.

Van Gundy, A., Bryant, A., \& Starks, B. C. (2013). Pushing the envelope for evolution and social change: Critical challenges for teaching inside-out. The Prison Journal, 93(2), 189-210. https://doi. org/10.1177/0032885512472691.

Publisher's Note Springer Nature remains neutral with regard to jurisdictional claims in published maps and institutional affiliations. 